\title{
Treatment of Baker's Yeast Wastewater with Freshwater Microalga and Its Green Chemistry Evaluation
}

\section{Tatlısu Mikroalgi ile Ekmek Mayası Atıksuyunun Arıtılması ve Yeşil Kimya Değerlendirmesi}

\author{
Research Article \\ Kadriye Oktor \\ Department of Environmental Engineering, Kocaeli University, Kocaeli, Turkey.
}

\section{A B S TRACT}

aker's yeast production processes require great amounts of high quality water, where it yields in formation of molasses wastewater and resistant COD (Chemical Oxygen Demand). The Chlorella variabilis microalgae application is studied and evaluated in this paper. The aim was to feed microalgae with the nutrients sustained by molasses; therefore, it was expected an observable growth of them and cleaning of the wastewater. Sample wastewater was 1- centrifuged to remove suspended solids, 2-diluted to various ratios, 3-incubated to grow microalgae, and 4- centrifuged to remove grown microalgae. Final analysis showed the efficiency of COD removal had been maximum $93.33 \%$. The greenness of the method was evaluated by examining the process with respect to principles of green chemistry. It is concluded that the proposed biotechnological approach satisfies 8 principles of green chemistry.

\section{Key Words}

Baker's yeast wastewater, COD removal, Chlorella variabilis microalgae, green chemistry.

\section{öz}

\begin{abstract}
- kmek mayası prosesi çok yüksek kalitede ve miktarda su kullanımına gereksinim duyar. Bunun sonucunda - dirençli KOi (Kimyasal Oksijen İhtiyacı) gibi farklı organik kirleticileri içeren yüksek oranda kirlenmiş atık sular ortaya çıkar. Bu çalışmada Chlorella variabilis mikroalgi uygulandı ve sonuçları değerlendirildi. Deneyin amacı melastan kaynaklı besinlerle mikroalgi büyütmektir. Bunun sonucunda mikroalg büyürken atık su da temizlenecektir. Atık su numunesi 1- askıda katı madde giderimi için santrifüjlendi, 2- farklı oranlarda seyreltildi, 3- mikroalg büyümesi için inkübe edildi ve 4- büyüyen mikroalgi ayırmak için santrifüjlendi. Sonuç analizlerinde KOi gideriminde en yüksek \%93,33 oranında verim elde edildi. Bu yöntemin yeşil metot olduğu yeşil kimya prensiplerine göre yapılan değerlendirmeyle incelendi. Değerlendirme sonucunda önerilen biyoteknolojik prosesin yeşil kimyanın 8 prensibini karşıladığı görüldü.
\end{abstract}

\section{Anahtar Kelimeler}

Ekmek mayası atık suyu, Koi giderimi, Chlorella variabilis mikroalgi, yeşil kimya.

Article History: Received: Mar 12, 2018; Revised: May 16, 2018; Accepted: Jul 6, 2018; Available Online: Oct 4, 2018.

DOI: $10.15671 /$ HJBC.2018.253

Correspondence to: K. Oktor, Department of Environmental Engineering, Kocaeli University, Kocaeli, Turkey. 


\section{INTRODUCTION}

Trea reatment of baker's yeast wastewater is a highly studied one among wastewater treatment topics since it has polluting characteristics, namely: high chemical and biochemical oxygen demand (COD and BOD), acidic properties of $\mathrm{pH}$ range 4-5, odor and color [1]. Molasses, which has high melanoidin, is the raw material for this specified manufacturing process and its untreated melanoidin can be detected in the discharged water due to the brown color and high COD [2]. In general, combined chemical and biological treatment methods are in use; yet, they are ineffective to decrease COD. These anaerobic and aerobic systems effectively reduce only BOD. To escalate the quality of the effluent water for availing the recycle of it, there are many methods are in use or under study as listed below:

- $\quad$ Membrane processes [3-5]

- Ultrasound technology $[2,6]$

- $\quad$ Nanofiltration $[7,8]$

- Electrocoagulation $[1,9,10]$

- $\quad$ Electrochemical processes $[5,7,11,12]$

- Chemical oxidation $[13,14]$

- $\quad$ Advanced oxidation processes [15]

- Adsorption $[16,17]$

- Coagulation/flocculation [18]

- Ozonizing [19-21]

Water treatment with microalgae is a novel approach based on biocatalysis. In literature, it has been shown that city sewages can be treated with microalgae as well as industrial and agricultural wastes [22] for the reason that microalgae decrease COD and BOD, eradicate coliform bacteria, consume phosphorus and nitrogen as energy resource and embody heavy metals exist in the media [23]. Additionally, biocatalysis is an environment friendlier alternative to conventional chemical treatment technology, while it reduces the use and consumption of severe chemicals and can be performed under mild temperaturepressure conditions.

Turkish legislative limits of COD in effluents from baker's yeast production facilities are 1200 $\mathrm{mg} / \mathrm{L}$ for 2 hours and $1000 \mathrm{mg} / \mathrm{L}$ for 24 hours composite samples [24]. Henceforth, it is aimed in this study to reach below this legislation limits by treating the effluent with Chlorella variabilis type of microalgae culture. In addition to its rapid growth characteristics, Chlorella variabilis is durable and resistant to different pollutants in wastewater. This unicellular organism having $5-8.5 \mu$ diameters contains vitamin, protein, nucleic acids, fatty acids, and enzymes as well as carotenoid, iron, iodine, zinc, magnesium, phosphorus, and calcium [25].

The study also includes greenness assessment of this offered unique technique. The assessment is, briefly, investigating a method according to 12 principles of green chemistry step by step and the greenness evaluation is basically to see how many of these principles are fulfilled [26]. This practical assessment method was performed on treatment of baker's yeast process wastewater with Chlorella variabilis microalgae to show that if this biotechnological method is environmentally friendly.

\section{MATERIALS and METHODS Experimental Setup}

In this study, the microalgae culture of Chlorella variabilis reproduction habitat was chosen as untreated discharge water of an industrial baker's yeast manufacturing facility. Firstly, the collected process wastewater was undergone pre-treatment of centrifuging for 20 minutes to get rid of solid impurities at $4000 \mathrm{rpm}$. Secondly, the sample was equally proportioned and diluted with tap water up to $40 \%$ of the raw wastewater sample. The characterization of the effluent after the treatment necessitates measurement of COD and cell growth. Therefore, DR2800 Hach Lange LCK 314 standard kit was used for the detection of COD content. Additionally, the screening of cell growth and aggregation was detected via optical density (OD) measurement at $680 \mathrm{~nm}$ by using Jenway 6800 UV Vis. spectrophotometer and calculated by using the following equation (1) [27]:

$$
\mu=\frac{\ln \left(O D_{2} / O D_{1}\right)}{t_{2}-t_{1}}
$$

where $\mathrm{OD}_{2}$ represents microalgae density at time $t_{2}$ (at the end of the growth phase) and $O D_{1}$ is the initial microalgae density at $t_{1}$. $O D$ unit is $\mathrm{gL}^{-1}$ and time unit is hours. Among collected data, maximum growth rate $\left(\mu_{\max }\right)$ was deducted through the logarithmic phase of the growth plots. 
The experimental protocol requires 20 days of incubation time at constant temperature $\left(27^{\circ} \mathrm{C}\right)$, well lightening, and continuous stirring under ambient pressure. Henceforth, pre-treated samples were cultured with respect to the protocol and in $250 \mathrm{~mL}$ open erlenmeyer flasks as shown in Figure 1. Each sample was incubated for 20 days under 200-rpm constant mixing on INNOVA 40 -shaking incubator- and lightening provided by $7 \mathrm{~W}$ 2700K LED lamp.

\section{Green Chemistry Analysis}

Green chemistry is quite a new branch of environmental chemistry aiming to guide researchers find green alternatives to current chemicals in terms of solvents, energy usage, poisonousness, and such. This new methodology was named by Paul T. Anastas and John C. Warner in 1991, who later established 12 principles of green chemistry in 1998 [28].
Each principle of green chemistry can be used as a directory for advancements in research and development studies. All these principles are summarized in the work of Celik and Yildiz (Table 1) [26]. Although each of them has been briefly explained, an example can be given to clarify: 6 th principle points out energy efficiency addressing to improvement of temperature and pressure conditions of a process. So, aiming to advance a process to actualize at or close to ambient temperature and pressure would result in more energy efficiency.

\section{RESULTS AND DISCUSSION Experimental Results and Discussion}

The studied wastewater sample was obtained from an industrial baker's yeast production factory from the outlet stream of process tank ahead of any treatments. This specimen was diluted to following ratios: $0 \%, 10 \%, 20 \%, 30 \%$, and $40 \%$ to be incubated for 20 days under light

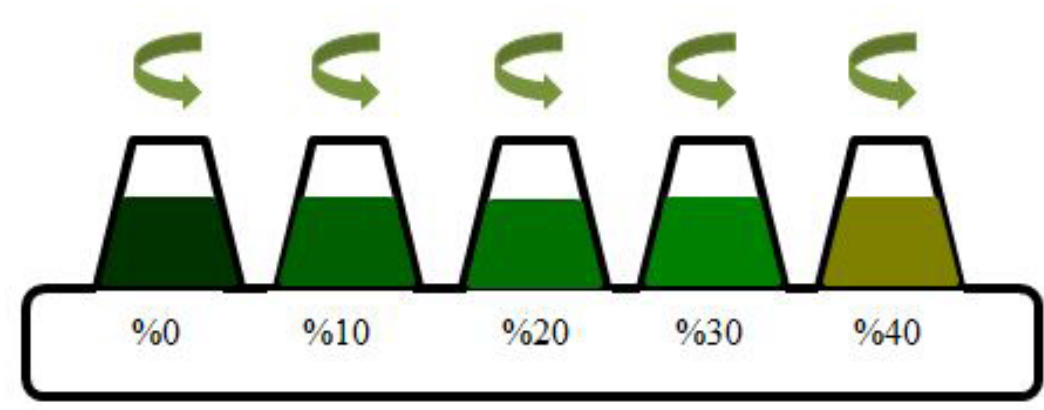

Figure 1. The experimental setup of microalgae treatment to baker's yeast manufacturing process wastewater.

Table 1. Green chemistry's 12 principles and their brief explanations. [26]

\begin{tabular}{ll}
\hline \multicolumn{1}{c}{ Principle } & \multicolumn{1}{c}{ Explanation } \\
\hline 1. Prevention & Preventing waste is better than cleaning. \\
\hline 2. Atom economy & To maximize the incorporation of all reagents used into the final product \\
\hline $\begin{array}{l}\text { 3. Less hazardous chemical } \\
\text { synthesis }\end{array}$ & Less toxic means lower hazard at workplace and to environment. \\
\hline 4. Designing safer chemicals & At design stage, the chemical toxicity should be minimized. \\
\hline 5. Safer solvents and auxiliaries & Solvents must be replaced with less toxic alternatives. \\
\hline 6. Energy efficiency & Synthetic methods having equilibrium conditions at or close to $\mathrm{T}_{\text {room }}$ and $\mathrm{P}_{\text {atm }}$. \\
\hline 7. Using renewable feedstock & Renewable feedstock should be used rather than depleting sources. \\
\hline 8. Reducing derivatives & Unnecessary derivatization should be minimized or avoided if possible, since they \\
& require additional reagents and generate waste. \\
\hline 9. Catalysis & Efficiency and yield of synthesis must be increased. \\
\hline 10. Designing for degradation & At the end of the useful life, items should be easily degraded. \\
\hline 11. Real-time analysis & In-process monitoring prior to hazardous substance formation. \\
\hline 12. Inherently safer chemistry & Raw materials and chemicals should be inherently safe. \\
\hline
\end{tabular}


at $27^{\circ} \mathrm{C}$. COD analysis was performed by using DR2800 Hach Lange LCK 314 standard cell kit. Pre-treatment and post-treatment COD measures and calculated removal ratios of each culture are given at Table 2 . The removal ratio percentage calculation is given in equation (2):

$\%$ Removal ratio $=\frac{\mathrm{COD}_{0}-\mathrm{COD}_{1}}{\mathrm{COD}_{0}} \times 100$

where $\mathrm{COD}_{0}$ is pre-treatment $\mathrm{COD}$ value and $\mathrm{COD}_{1}$ is post-treatment COD value.

The results demonstrate that microalgae use for treating this industrial wastewater have been successful by lowering COD to almost of the legislative limits. Moreover, it is deduced from the results that pre-dilution can be omitted for this specific type of microalgae treatment systems. One another result states that maximum growth rate was obtained in undiluted culture. The cell growth rate of undiluted culture is calculated as $\mu_{\max }=0.0038 \mathrm{~h}^{-1}$.

In literature, microalgae treatment of various wastewater COD removal efficiencies has been studied. Kshirsagar et.al. studied sewage water treatment of Pune City /India by using Chlorella vulgaris and Scenedesmus quadricauda. In this study, it was found that COD removal ratios were $80.64 \%$ and $70.97 \%$ respectively [29]. Zhu et.al., on the other hand, studied with a different microalgae type of Chlorella family, Chlorella zofingiensis for COD removal of piggery wastewater. The researchers stated that $79.84 \%$ COD removal obtained [30]. Microalgae treatment of yeast industry wastewater was not found in literature. Henceforth, COD removal results of other wastewaters using Chlorella family (vulgaris and zofingiensis) microalgae were compared with current Chlorella variabilis application. It can be observed from the results that, this specific type of Chlorella microalgae family member, Chlorella variabilis, has shown the most efficient COD removal ratio from yeast industry wastewater.

\section{Green Chemistry Analysis Results and Discussion}

The aforementioned green chemistry analysis was performed step by step to evaluate this proposed microalga treatment biotechnology in order to define environmental characteristics of it. However, it should be denoted that this analysis does not concern economics of the processes. Though each principle investigated thoroughly under given subsection, the overall analysis can be given here. The study shows that this novel treatment technology satisfies all the green chemistry aspects in terms of being environment friendly, non-toxic, non-hazardous, energy efficient, catalysis, and sustainability; but 4 out of 12 principles are about chemical synthesis and industrial applications, and they are not applicable for this type of process.

\section{Prevention}

Conventional treatment technologies end up with formation of sludge. This generated sludge becomes a waste issue to be managed further; even they could be toxic or dangerous. But microalgae treatment creates no further wastes to be managed. It is safe to say waste prevention is achieved by taking biotechnological measures.

\section{Atom Economy}

Atom economy means to see all the atoms of inlet at the desired final product. In other words, it is preservation of mass but at the specific product. Thus, any formation of a side product conflicts with atom economy principle. For this studied

Table 2. Pre-treatment and post-treatment COD analysis results and calculated removal ratio.

\begin{tabular}{cccc}
\hline Dilution & $\begin{array}{c}\text { Pre-treatment COD } \\
(\mathrm{mg} / \mathrm{L})\end{array}$ & $\begin{array}{c}\text { Post-treatment COD } \\
(\mathrm{mg} / \mathrm{L})\end{array}$ & Removal ratio \\
\hline $0 \%$ & 2500 & 172 & $93.12 \%$ \\
\hline $10 \%$ & 2250 & 150 & $93.33 \%$ \\
\hline $20 \%$ & 2000 & 173 & $91.25 \%$ \\
\hline $30 \%$ & 1750 & 140 & $92.00 \%$ \\
\hline $40 \%$ & 1500 & 142 & $90.53 \%$ \\
\hline
\end{tabular}


treatment system, inlet is the consumables in the waste water and any product formation would be a side product. Microalgae culture uses the inlet as feed and grows in scale only and accompanied with no another product. Therefore, atom economy is fulfilled.

\section{Less Hazardous Chemical Synthesis}

This principle is the first of the four not applicable principles as there is no chemical synthesis. Basically, it is about the toxic risks of substances necessary for a chemical synthesis. The aim is to define an alternate route for a chemical synthesis in order to make it less toxic on environment and work place.

\section{Designing Safer Chemicals}

This is the second of the four not applicable principles as this process contains no chemical design stage. Briefly, this principle is choosing a toxic chemical to study on and replace it with a safer alternative to be used with the same purposes.

\section{Safer Solvents and Auxiliaries}

The situated practice of wastewater treatment of baker's yeast process is a combination of advanced chemical and biological techniques. Even though biological treatment take place under milder conditions, advanced chemical technologies requires employment of severe chemicals. On the contrary, biotechnological methodology based on a living culture, extreme chemicals have to be avoided to keep them alive. To conclude, safer solvents and auxiliaries are employed.

\section{Energy Efficiency}

This principle is about performing the process as much closer as possible to ambient temperature and pressure. During the evaluation of this one, conventional and novel methods are not compared with each other since process conditions changes from facility to facility. The process conditions for this study are ambient pressure and $27^{\circ} \mathrm{C}$; which can be assumed as room conditions. Hence, this method is an energy efficient method.

\section{Using Renewable Feedstock}

Rather than consuming synthetic chemicals used for chemical treatment technologies, microalga reproduces and cultures itself which makes them a sustainable feedstock.

\section{Reducing Derivatives}

The difference between this principle and atom economy is the mid-steps are focused here whereas the final product is under concern for atom economy. However, the satisfaction of atom economy mostly goes parallel with satisfaction of derivative reduction as in the case of this particular purification study.

\section{Catalysis}

Catalysis onto a system can be done with the aim of increasing efficiency, decreasing energy requirements, more selectiveness, or all mentioned. Because enzymes are biological catalysts, this principle of green chemistry is actualized by microalga enzymes. Moreover, biocatalyst use makes it even greener than that of employing synthetic catalysts.

\section{Designing for Degradation}

Biodegradability is an important marker for environmental properties. The only product of this purification biotechnology is grown microalga, which is biodegradable or, even better, can be an input for some other sustainable productions. A combination of those system productions would make them greener. Until then, degradation is readily sustained in this system.

\section{Real-time Analysis}

Especially during the production of hazardous or toxic chemicals, or extreme production conditions in terms of very high/low temperature and/or pressures, and processes that have dangerous mid-products should be monitored carefully to protect workers and environment. Although this principle is all about industrial applications and are not applied for laboratory scale studies, it can be foreseen that a scale up of this technology should include real-time analysis. But it has been counted as not applicable for this study.

\section{Inherently Safer Chemistry}

Inherent safety is all about the safety of the substances used in chemical synthesis and their forms. To explain more, this principle leads to minimize the potential likelihood of chemical 
accidents, releases, explosions or fires. Although the microalgae method is safer than conventional methods, it is not because of inherent safety, but because of other properties discussed above.

To finally sum up, the satisfied principles of green chemistry are 8 out of 12 and they are namely Prevention, Atom economy, Safer solvents and auxiliaries, Energy efficiency, Using renewable feedstock, Reducing derivatives, Catalysis, and Designing for degradation. Remaining 4 of 12 principles are the not applicable ones: Less hazardous chemical synthesis, Designing safer chemicals, Real-time analysis, and Inherently safer chemistry.

\section{CONCLUSIONS}

Baker's yeast manufacturing industry seeks for a better wastewater treatment alternative to get rid of the odor and color caused by the melanoidin in the outlet stream of the process tanks; and it is not only because of legislative responsibilities, but also importance on public and environmental health. The reason of the remaining color and odor is because of the remaining unprocessed melanoidin; furthermore, this melanoidin also increases COD and BOD in the stream. Currently, $B O D$ is successfully decreased beyond limits, but COD removal must be improved. Therefore, it can be deduced from given information that an improvement on decreasing COD would improve color and odor recognizably. This study focuses on COD levels and offers a novel approach by means of using microalgae for this specified industrial wastewater. It can be observed from the numerical results that employing microalgae culture, specifically Chlorella variabilis, effectively consumes waste materials in the stream and improve final COD levels up to of the untreated stream. Another result can be reckoned as dilution of process could be skipped since it makes a negligible difference on COD levels; moreover, no diluted sample showing maximum growth rates states that purification would work in shorter time of period. Hence, direct application of the treatment is recommended. Lastly, to point out the environmentally friendliness of this new biotechnological advancement, green chemistry analysis has been applied to the overall system.
The analysis results demonstrate that every applicable principle of green chemistry -that is 8 out of $12^{-}$are satisfied by the system and its components. Even though the economic feasibility has been disregarded, the overall greenness makes it worthwhile to study further on industrialization of this advanced biotechnology.

\section{ACKNOWLEDGMENTS}

The author would like to thank Togayhan Kutluk and Dicle Çelik for their assistance in laboratory works and analysis. The author thanks Kocaeli University Chemical Engineering Department Biotechnology Laboratory for cultivation of microalgae.

\section{References}

1. E. Gengec, M. Kobya, E. Demirbas, A. Akyol, K.Oktor, Optimization of baker's yeast wastewater using response surface methodology by electrocoagulation, Desalination, 286 (2012) 200-209.

2. D. Ildırar, S. Fındık, Effect of operational parameters on ultrasonic treatment of baker's yeast effluent, SAÜ Fen Bil. D., 20 (2016) 185-191.

3. I. Koyuncu, F. Yalcın, I. Ozturk, Color removal of high strength paper and fermentation effluents with membrane technology, Water Sci. Technol. 40 (1999) 241-248.

4. G. Balcıoğlu, Z.B. Gönder, Recovery of baker's yeast wastewater with membrane processes for agricultural irrigation purpose: Fouling characterization, Chem. Eng. J., 255 (2014) 630-640.

5. S.H. Mutlu, U. Yetis, T. Gurkan, L. Yilmaz, Decolorization of wastewater of a baker's yeast plant by membrane processes, Water Res., 36 (2002) 609616.

6. D. Ildırar, Maya endüstrisi atıksuyunun ultrases ile koyu renginin giderilmesi, M.Sc., Hitit Üniv., 2014.

7. M. Liu, H. Zhu, B. Dong, Y. Zheng, S. Yu, C.Gao, Submerged nanofiltration of biologically treated molasses fermentation wastewater for the removal of melanoidins, Chem. Eng. J., 223 (2013) 388-394.

8. A. Rahimpour, M. Jahanshahi, M. Peyravi, Development of pilot scale nanofiltration system for yeast industry wastewater treatment, J. Environ. Health Sci., 1255 (2014) 1-7.

9. J.N. Hakizimana, B. Gourich, M. Chafi, Y. Stiriba, C. Vial, P. Drougi, J. Naja, Electrocoagulation process in water treatment: A review of electrocoagulation modeling approaches, Desalination, 404(2017) 1-21.

10. M. Al-Shannag, Z. Al-Qodah, K. Alananbeh, N. Bouqellah, E. Assirey, K. Bani-Melhem, COD reduction of baker's yeast wastewater using batch electrocoagulation, Environ. Eng. and Manag. J., 13 (2014) 3153-3160.

11. G. Balcıoğlu, Z.B. Gönder, Recovery of baker's yeast wastewater with membrane processes for agricultural irrigation purpose: Fouling characterization, Chem. Eng. J., 255 (2014) 630-640. 
12. S. Basu, S. Mukherjee, A. Kaushik, V.S. Batra, M. Balakrishnan, Integrated treatment of molasses distillery wastewater using microfiltrafion, J. Environ. Manag., 158(2015) 55-60.

13. T. Ünal, Ekmek mayası endüstrisi seperasyon prosesi atıksularında ozon ve ozon/hidrojen peroksit oksidasyonu ile renk giderimi, M.Sc., ITÜ., 2011.

14. A. Pala, G. Erden, Decolorization of a baker's yeast industry effluent by fenton oxidation, J. Hazard. Mater. B, 127 (2005) 141-148.

15. E. Yılmaz, S. Fındık, Photocatalytic treatment of baker's yeast effluent using UV light and $\mathrm{TiO} / \mathrm{ZnO}$ composite, CBÜ Fen Bil. D., 12 (2016) 609-615.

16. Y. Xia, L. Meng, Y. Jiang, Y. Zhang, X. Dai, M. Zhao, Facile preparation of $\mathrm{MnO} 2$ functionalized baker's yeast composites and their adsorption mechanism for cadmium, Chem. Eng. J., 259 (2015) 927-935.

17. Y. Zhang, J. Zhu, L. Zhang, Z. Zhang, M. Xu, M. Zhao, Synthesis of EDTAD-modified magnetic baker's yeast biomass for $\mathrm{Pb}+2$ and $\mathrm{Cd}+2$ adsorption, Desalination, 278 (2011) 42-49.

18. L. Fan, T. Nguyen, F. Roddick, Characterisation of the impact of coagulation and anaerobic bio-treatment on the removal of chromophores from molasses wastewater, Water Res., 45 (2011) 3933-3940.

19. M. Mischopoulou, P. Naidis, S. Kalamaras, T.A. Kotsopoulos, P. Samaras, Effect of ultrasonic and ozonation pretreatment on methane production potential of raw molasses wastewater, Renew. Energ. 96 (2016) 1078-1085.

20. C. Tsioptsias, G. Lionta, A. Deligniannis, P. Samaras, Enhancement of the performance of a combined microalgae-activated sludge system for the treatment of high strength molasses wastewater, J. Environ. Manag., 183 (2016) 126-132.
21. Y.F. Zeng, Z.L. Liu. Z.Z. Qin, Decolorization of molasses fermentation wastewater by SnO2-catalyzed ozonation. J. Hazard. Mater., 162 (2015) 682-687.

22. S. Satpal, A.K. Khambete, Wastewater treatment using microalgae - A review paper, IJETMAS, 4 (2016) 188192.

23. N. Abdel-Raouf, A.A. Al-Homaidan, I.B.M. Ibraheem, Microalgae and wastewater treatment, Saudi J. Bio. Sci., 19 (2012) 257-275.

24. Department of Legislation, Prime Ministry website [Online]. Available: http://mevzuat.basbakanlik.gov.tr, (12.03.2018).

25. I. Shihira, R.W. Krauss, Chlorella: Physiology and taxonomy of forty-one isolates, Uni. Maryland, College Park, Maryland, 1965.

26. D. Çelik, M. Yıldız, Investigation of hydrogen production methods in accordance with green chemistry principles, Int. J. Hydrogen Energy, 42 (2017) 23395-23401.

27. F. Widdel, Theory and measurement of bacterial growth, Bremen University, 2010.

28. P.T. Anastas, J.C. Warner, Green chemistry: theory and practice, Oxford University Press, New York, USA, 1998.

29. A.D. Kshirsagar, Bioremediation Of Wastewater By Using Microalgae: An Experimental Study, Int. J. LifeSc. Bt \& Pharm. Res. 2 (2013) 339-346.

30. L. Zhu, Z. Wang, Q. Shu, J. Takala, E. Hiltunen, P. Feng, Z. Yuan, Nutrient removal and biodiesel production by integration of freshwater algae cultivation with piggery wastewater treatment, Water Research 47 (2013) 4294-4302. 